\title{
Struktur Kalimat pada Film Knives Out Berdasarkan Perspektif Tata Bahasa Kasus Charles J. Fillmore
}

\author{
Sentence Structure in Film "Knives Out" Based on the Perspective of Charles J. \\ Fillmore's Case Grammar
}

\author{
Abdul Basid ${ }^{1, *}$, Habib Insan Kamil' ${ }^{2}$, dan Mutma Innah ${ }^{3}$ \\ ${ }^{1,2,3}$ Bahasa dan Sastra Arab, Fakultas Humaniora, \\ UIN Maulana Malik Ibrahim Malang \\ ${ }^{1}$ Corresponding email: abdulbasid@bsa.uin-malang.ac.id \\ ${ }^{2}$ Email: habibkami155@gmail.com \\ ${ }^{3}$ Email: mutma38@gmail.com
}

Received: 2 Maret 2021 Accepted: 17 July 2021 Published: 1 August 2021

\begin{abstract}
This study aims to reveal the sentence structure of the film Knives Out based on the grammatical perspective of the case of Charles J. Fillmore. This research is descriptive qualitative research. Data collection techniques consist of 3 kinds of techniques, namely watching, reading, and taking notes. The data that has been collected is then analyzed using a distributional method with basic techniques: segmenting immediate constituents techniques, which is a method that in determining identity uses a determining tool in language units that divides a construction of direct elements that shape it. The results of this study indicate that the sentence structure in the film Knives Out consists of (1) four modalities, namely intentional, epistemic, deontic, and dynamic, and (2) ten propositions, namely: agentive case $(A)$, experiential case $(P)$, instrument case (I), objective case $(O)$, source case $(S)$, destination case $(T)$, locative case $(L)$, timing case $(W)$, accompanying case (PNY), and beneficial case (B).
\end{abstract}

Keywords: case, grammar, modality, proposition, structure

\begin{abstract}
Abstrak: Tujuan penelitian ini adalah untuk mengungkap struktur kalimat pada film Knives Out berdasarkan perspektif tata bahasa kasus Charles J. Fillmore. Penelitian ini termasuk penelitian kualitatif deskriptif. Teknik pengumpulan data terdiri dari 3 macam teknik, yaitu tonton, baca, dan catat. Data yang sudah terkumpul, kemudian dianalisis dengan menggunakan metode distribusional dengan teknik dasar: teknik bagi unsur langsung (segmenting immediate constituents techniques), yaitu sebuah metode yang dalam menentukan identitas menggunakan alat penentu di dalam satuan bahasa yang membagi suatu konstruksi atas unsur-unsur langsung yang membentuknya. Hasil penelitian ini menunjukkan bahwa struktur kalimat pada film Knives Out terdiri atas: (1) empat modalitas, yaitu intensional, epistemik, deontik, dan dinamik; dan (2) sepuluh proposisi, yaitu: kasus agentif (A), kasus eksperiens (P), kasus instrumen (I), kasus objektif (O), kasus sumber (S), kasus tujuan (T), kasus lokatif (L), kasus waktu (W), kasus penyerta (PNY), dan kasus benefaktif (B).

Kata kunci: kasus, modalitas, proposisi, tata bahasa, struktur
\end{abstract}

To cite this article:

Basid, A., Kamil, H. I., \& Innah, M. (2021). Struktur Kalimat pada Film Knives Out Berdasarkan Perspektif Tata Bahasa Kasus Charles J. Fillmore. Diglosia: Jurnal Kajian Bahasa, Sastra, dan Pengajarannya, 4(3), 301—320. https://doi.org/10.30872/diglosia.v4i3.209 


\section{A. PENDAHULUAN}

Setiap bahasa mempunyai cara tersendiri dalam menyampaikan serta mengekspresikan sebuah tuturan. Kita bisa berselisih pendapat yang disebabkan oleh perbedaan maksud antara penutur dan mitra tutur. Karena itu tata bahasa berguna dalam mengkomunikasikan segala makna kompleks yang terdapat pada hubungan antar kata secara teratur. Apabila seseorang ingin mengetahui kebenaran siapa yang memperhatikan siapa, tata bahasa dapat memudahkan kita mencari tahu dengan mengunakan berbagai strategi seperti urutan kata, kesepakatan verbal, dan penandaan kasus. Dari sekian banyak strategi penggunaan bahasa, hanya beberapa peneliti yang sangat terampil menelaah permasalahan penggunaan bahasa tersebut, seperti tata bahasa kasus (Jurafsky, 2014, pp. 725-731; Trijp, 2017, p. 1).

Tata bahasa kasus menjadi penting karena masih minimnya penelitian yang menyangkut penerimaan makna (semantik) oleh resipien (Miller, Shibatani, \& Thompson, 1997). Dalam tata bahasa kasus ini, pengurutan kata yang berbeda dapat menimbulkan persepsi makna yang berbeda, tetapi ada juga kalimat yang apabila dilakukan parafrase menghasilkan makna yang sama dengan sebelumnya.

Kita dapat menemukan berbagai jenis tata bahasa kasus pada kegiatan seharihari, seperti dalam sebuah percakapan, dialog pada film, maupun narasi yang terdapat dalam novel. Pada penelitian ini peneliti memilih film Knives Out sebagai objek penelitian. Alasannya adalah karena dalam film ini memiliki kalimat dengan tata bahasa kasus yang cukup kompleks dan rumit. Hal ini lebih dikarenakan tuntutan skenario yang digunakan untuk menceritakan kejadian pembunuhan. Alur cerita yang digunakan dalam film ini yaitu maju mundur, sehingga menyebabkan penonton ikut berpikir dan mendapatkan persepsi yang berbeda terhadap kejadian pembunuhan tersebut.

Teori tata bahasa kasus yang dikembangkan oleh Charles J. Fillmore merupakan hasil pengembangan dari teori tata bahasa tradisional yang berada pada tatanan gramatika atau semantik (D'Angelo, 1976, pp. 359-362; Lakoff, 2014, pp. 251257). Fillmore memperkenalkan teorinya ini pada tahun 1968 dengan judul The Case for Case. Pada teorinya ini, Fillmore menempatkan peran kata dalam sebuah kalimat (Tarigan, 2009, p. 54; Chaer, 2007, p. 370; Ackerman, Kay, \& O'Connor, 2014, pp. 755-761).

Adapun kaidah yang telah ditentukan oleh Fillmore, yaitu: (1) Pada struktur dasar kalimat, kita dapat menemukan modalitas dan proposisi (Suparnis, 2008, pp. 126-131). Sifat pasti dari konstituen modalitas dapat diabaikan untuk tujuan kita, akan tetapi sangat mungkin pada kasus tertentu bisa berhubungan langsung dengan konstituen modalitas karena yang lain terkait dengan proposisi itu sendiri, misalnya, kata keterangan temporal tertentu (Chu, 1999, pp. 29-34). Maka, aturan dasar pertama adalah: Sentence $\rightarrow$ Modality + Proposition atau bisa kita singkat $\mathrm{S} \rightarrow$ $\mathrm{M}+\mathrm{P}$; (2) $\mathrm{P}$ (proposisi) di dalamnya terdapat kata kerja dan satu atau lebih kategori kasus. Perluasan $\mathrm{P}$ dapat dirumuskan Proposition $\rightarrow \mathrm{Verb}+\mathrm{Case}_{1}+\ldots+$ Case $_{n}$ disingkat $\mathrm{P} \rightarrow \mathrm{V}+\mathrm{C}_{1}+\ldots+\mathrm{C}_{\mathrm{n}}$, di mana setidaknya satu kategori kasus harus dipilih dan tidak ada kategori kasus yang muncul lebih dari satu kali. Dalam pembahasan ini kita menganggap $P$ dapat diwakili oleh salah satu himpunan rumus termasuk $\mathrm{V}+\mathrm{A}, \mathrm{V}+\mathrm{O}+\mathrm{A}, \mathrm{V}+\mathrm{D}, \mathrm{V}+\mathrm{O}+\mathrm{I}+\mathrm{A}$, dan seterusnya; (3) Adapun $\mathrm{C}$ (kasus) dapat kita ketahui dengan $\mathrm{C} \rightarrow \mathrm{NP}+\mathrm{K}, \mathrm{K}+\mathrm{NP}$. NP merupakan Noun Phrase (frasa nomina) yang diikuti dengan $\mathrm{K}$ (pengantar kasus) atau sebaliknya. $\mathrm{K}$ di sini bisa berupa preposisi, postposisi maupun suplementer; (4) Noun Phrase tersusun dari 
$\mathrm{NP} \rightarrow \mathrm{d}+\mathrm{N}, \mathrm{N}+\mathrm{d}, \mathrm{N}(\mathrm{k}), \mathrm{N}+\mathrm{n}$ (posesif). Huruf $\mathrm{d}$ merupakan simbol dari definitif yang menyatakan sesuatu yang ditunjuk seperti the, kemudian diikuti dengan Noun (nomina) yang merupakan kata benda. Bisa juga huruf d digantikan oleh nomina berupa klausa non-finit maupun nomina yang diikuti possessive pronoun (kata ganti kepemilikan seseorang maupun kelompok) (Fletcher, 1971, pp. 237-250; Pak, 1974, pp. 19-50; Anderson, 1986, pp. 79-129).

Peneliti menggunakan teori tata bahasa kasus berdasarkan perspektif Charles J. Fillmore yang dianggap valid dalam menelaah struktur kalimat pada bahasa Inggris karena pada teori ini dapat menjelaskan peran semantik (deep structure) menggunakan struktur kalimat yang terdiri dari modalitas dan proposisi, yang mana di dalam proposisi terdapat suatu penandaan yang disebut sebagai kasus (Cook \& Platt, 1970, p. 262; Nuessel, 1981, pp. 83-88).

Dalam konteks penelitian tata bahasa kasus Charles J. Fillmore, peneliti menemukan beberapa penelitian terdahulu. Pertama, Indrawati, dkk berjudul Pelabelan Peran Semantis Menggunakan Tata Bahasa Kasus yang memaparkan penggunaan pelabelan peran semantis pada konsep dari suatu kalimat dalam dokumen teks (Indrawati, Bijaksana, \& Agustin, 2013, pp. 85-86). Kedua, Abdul Basid dan Indah Rahmi Inayati berjudul Tata Bahasa Kasus Dalam Film Upin dan Ipin Berdasarkan Perspektif Charles J. Fillmore yang menjabarkan modalitas dan mendeskripsikan proposisi dalam film Upin dan Ipin (Basid \& Inayati, 2020, pp. 35). Ketiga, Alfadhil dan Rahmadi berjudul Tata Bahasa Kasus Dalam Sosial Media Tweet Rocky Gerung Berdasarkan Perspektif Charles J. Fillmore yang menganalisiskan jenis dan bentuk tata bahasa kasus pada tweet Rocky Gerung (Alfadhil \& Rahmadi, 2020, pp. 69-71). Keempat, Basid, Arzaqi, dan Afiyanto yang mengungkapkan tata bahasa kasus dalam film "the Professor and the Madman" berdasarkan perspektif Charles J. Fillmore (Basid, Arzaqi, \& Afiyanto, 2021). Kelima, Basid dan Maghfiroh yang mendeskripsikan tata bahasa kasus dalam film "the Gentlemen" berdasarkan perspektif Charles J. Fillmore (Basid \& Maghfiroh, 2021).

Dari kelima penelitian di atas, peneliti menemukan adanya persamaan dan perbedaan dengan penelitian yang peneliti lakukan ini. Adapun persamaannya terdapat pada penggunaan teori tata bahasa kasus berdasarkan perspektif Charles J, Fillmore, jenis penelitian kualitatif deskriptif, dan film. Sedangkan perbedaannya terletak pada objek dan fokus kajian. Penelitian pertama memjabarkan pada textmining dalam dokumen, penelitian kedua membahas pada tata bahasa kasus pada film berbahasa Melayu, penelitian ketiga menganalisis kalimat pada media sosial twiter, penelitian keempat dan kelima mengeksplorasi tata bahasa kasus dalam film berbahasa Inggris, yaitu film "the Professor and the Madman" dan "the Gentlemen." Sedangkan, penelitian ini mengungkap struktur kalimat dalam film berbahasa Inggris yang berjudul Knives Out dengan menggunakan teori yang sama, yaitu tata bahasa kasus Charles J. Fillmore.

Berdasarkan pada persamaan dan perbedaan, maka posisi penelitian ini adalah untuk menambahkan temuan tata bahasa kasus dalam film berbahasa Inggris. Jadi dapat disimpulkan bahwa penelitian terdahulu di atas dapat menjadi rujukan atau dasar dalam melakukan penelitian ini. Adapun tujuan penelitian ini adalah mengungkap struktur kalimat pada film Knives Out berdasarkan perspektif tata bahasa kasus Charles J. Fillmore. 


\section{B. METODE}

Penelitian ini termasuk jenis penelitian kualitatif deskriptif, dimana pemikiran peneliti sesuai dengan hasil data yang diharapkan (Ezzy, 2002, pp. 2-3). Data dalam penelitian ini berupa kalimat yang memiliki struktur: SP, SPO, dana tau SPOK yang terdapat dalam film Knives Out. Teknik pengumpulan data yang digunakan adalah teknik tonton, teknik baca, dan teknik catat. Peneliti menonton film untuk mendapatkan gambaran keseluruhan cerita dan berfungsi untuk melihat konteks dimana kalimat diujarkan. Peneliti membaca subtitle berbahasa Indonesia dan dilengkapi dengan membaca subtitle berbahasa Inggris untuk mendapatkan kesamaan makna kalimat dan juga sekaligus validasi terhadap kalimat-kalimat yang diujarkan para aktor. Peneliti mencatat setiap kalimat dan mengkroscek kembali dengan menonton secara berulang-ulang.

Setelah mendapatkan data kemudian peneliti melakukan validasi data. Validitas data berasal dari sampel data penelitian yang kemudian diuji kebenarannya serta dapat dipertanggung jawabkan (Bauer \& Gaskell, 2007, pp. 143-144). Teknik validasi data terdiri dari tiga macam, yaitu: (1) meningkatkan ketekunan, yaitu peneliti melakukan keseluruhan teknik pengumpulan data berulang-ulang, dan (2) diskusi, yaitu peneliti mendiskusikan kembali data yang telah peneliti dapatkan untuk mendapatkan kesamaan pemahaman terhadap data tersebut.

Analisis data menggunakan metode distribusional dengan teknik dasar: teknik bagi unsur langsung (segmenting immediate constituents techniques), yaitu sebuah metode yang dalam menentukan identitas menggunakan alat penentu di dalam satuan bahasa yang membagi suatu konstruksi atas unsur-unsur langsung yang membentuknya (Zaim, 2014, p. 101). Oleh karena itu langkah-langkah yang dilakukan peneliti untuk menganalisis data (struktur kalimat) adalah sebagai berikut: (1) peneliti menganalisis konstituen pembentuk kalimat berdasarkan $\mathrm{S}+\mathrm{P}+\mathrm{O}+\mathrm{K}$; (2) peneliti mencermati ciri-ciri dari setiap konstituen yang membentuk $\mathrm{S}+\mathrm{P}+\mathrm{O}+\mathrm{K}$; dan (3) peneliti menganalisis setiap bagian konstituen dan juga dalam keselurahan konstruksi kalimat untuk menentukan sub tata bahasa kasus: jenis modalitas dan proposisi sesuai dengan teori tata bahasa kasus Charles J. Fillmore.

\section{PEMBAHASAN}

Struktur dalam (deep structure) sebuah kalimat merupakan sebuah wilayah kajian dalam tata bahasa kasus yang dapat diungkap dengan menggunakan analisis sintaksis. Struktur dalam yang dimaksud di sini adalah semantika dalam kalimat (Nuessel, 1981, pp. 83-88). Teori ini berkaitan dengan teori tata bahasa generatif yang dipelopori oleh Pike yang dianggap belum sempurna dalam mengungkap komposisi semantik pada sebuah kalimat. Fillmore membagi struktur kalimat menjadi 2 unsur, yaitu modalitas dan proposisi, yang mana pada proposisi inilah kita bisa mengungkapkan kasus di dalam kalimat (Parera, 2009, p. 139; Tarigan, 2009, p. 60; Verhaar, 2010, p. 89). Adapun penjelasannya adalah sebagai berikut. 
Tabel 1. Jenis Modalitas dan Bentuknya

\begin{tabular}{lll}
\hline Unsur Tata Bahasa Kasus & Jenis Modalitas & Bentuk Modalitas \\
\hline Modalitas & Intensional & Keinginan \\
& & Harapan \\
& & Ajakan \\
& & Pembiaran \\
& Epistemik & Permintaan \\
& Kemungkinan \\
& Keteramalan \\
& Keharusan \\
& Deontik & Kepastian \\
& Perizinan \\
& Dinamik & Perintah \\
& & Kemampuan \\
\hline
\end{tabular}

\section{Modalitas}

Modalitas merupakan sikap penutur terhadap proposisi atau suatu peristiwa yang dilandasi dengan kaidah rasional, sosial maupun hukum alam. Menurut Alwi terdapat empat jenis modalitas yaitu intensional, epistemik, deontik, dan dinamik (Alwi, 1992, p. 16; Gustianingsih, 2008, p. 45). Dalam film Knives Out, peneliti menemukan keempat jenis modalitas tersebut dan kemudian peneliti sajikan dalam Tabel 1 di bawah ini. Masing-masing jenis modalitas: intensional, epistemik, deontik, dan dinamik memiliki berbagai macam. Berikut dipaparkan jenis modalitas dan bentuknya tersebut.

\section{a. Intensional}

Modalitas intensional merupakan modalitas yang menyatakan sikap penutur terhadap peristiwa non-faktual atau masih belum terjadi. Penutur menjadi tolak ukur dalam aktualisasi makna (Alwi, 1992, p. 52). Dalam film Knives Out, peneliti menemukan lima bentuk modalitas intensional.

\section{(1) Keinginan}

Modalitas intensional bermakna keinginan pada dasarnya disebabkan oleh faktor peluang dan keadaan. Faktor peluang memiliki pengaruh pada pelaksanaan peristiwa, sedangkan faktor keadaan mempengaruhi kebutuhan dan prospek.

$$
\begin{aligned}
& \text { Wagner : "We'd like to see you one at a time." } \\
& \text { Linda : "All right. Uh, I'll go first." } \\
& \text { Wagner : "Kami ingin memeriksa kalian satu per satu" } \\
& \text { Linda : "Baik. Aku duluan" } \\
& \text { (Johnson, 2019, 00:05:12) }
\end{aligned}
$$

Dalam ucapan Wagner terdapat kata like yang berarti mengingingkan. Ingin yang dimaksud dalam ucapannya ini adalah akan karena dalam konteks ucapan tersebut Wagner akan melakukan pemeriksaan terhadap anggota keluarga Harlan.

Linda : "It's just not the same."

Blanc : "But surely Walt runs the merchandising..." 


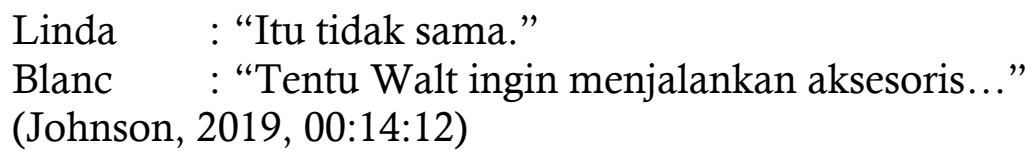

Dalam perkataan Blanc "But surely Walt runs the merchandising..." terdapat kata surely yang memiliki makna ingin. Namun, kata surely di sini berarti mendapatkan bisnis aksesoris yang dimiliki oleh Harlan.

Harlan : "My mind's made up."
Walt
Harlan :You want to talk about an argument."
Walt :Keputusanku sudah bulat
(Johnson, 2019, 00:16:38)

Pada kalimat You want to talk about an argument, terdapat kata want yang memiliki arti ingin. Ingin yang dimaksud dalam konteks kalimat tersebut adalah akan membahas percekcokan yang terjadi.

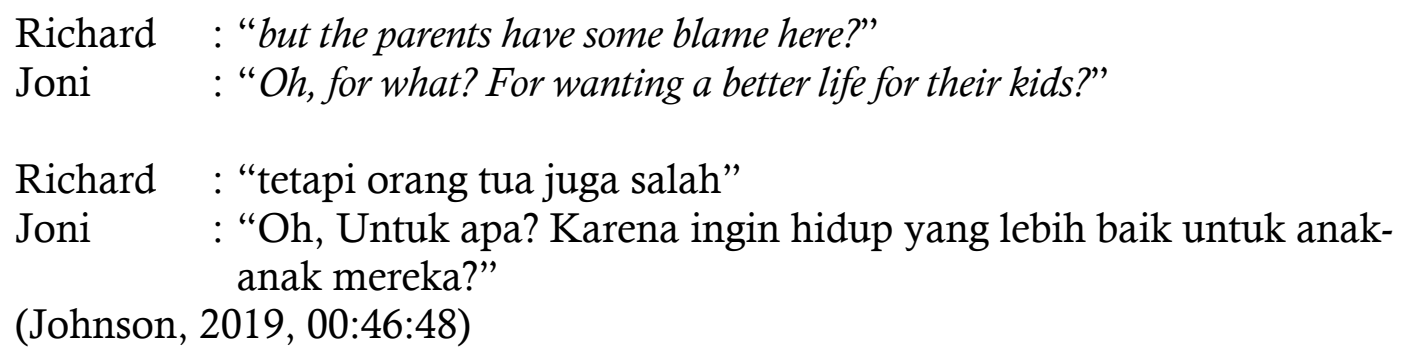

Pada kalimat For wanting a better life for their kids? Terdapat kata wanting. Wanting merupakan sebuah gerund - menominakan kata kerja. Ingin yang dimaksud pada konteks kalimat tersebut adalah mendapatkan, yaitu ingin mendapatkan kehidupan yang layak.

\section{(2) Harapan}

Modalitas intensional dengan makna harapan merupakan modalitas yang berfungsi untuk menyatakan keadaan penutur mengharapkan sesuatu bisa terjadi, walaupun hanya terlihat angan-angan atau nonfaktual.

$$
\begin{aligned}
& \text { Marta : "Don't make me get the belt, abuelo." } \\
& \text { Harlan : "My only hope is that an earthquake will strike." } \\
& \text { Marta : "Jangan sampai aku mengambil sabuk, Kakek" } \\
& \text { Harlan : "Aku hanya berharap ada gempa" } \\
& \text { (Johnson, 2019, 00:33:38) }
\end{aligned}
$$

Berdasarkan perkataan Harlan di atas, peneliti mendapati adanya kata hope dalam My only hope is that an earthquake will strike yang bermakna Harlan berharap jika pada hari itu terjadi gempa sehingga dia tidak akan disusahkan dalam urusan harta kepada anak turunnya. 


\section{(3) Ajakan}

Modalitas intensional bermakna ajakan merupakan modalitas yang befungsi mengajak persona pertama, kedua maupun ketiga untuk melakukan suatu hal yang dikatakan oleh penutur.

Elliot : "Come on, Benny, talk to me, all right? Now, you tell me to invite all of the people back for questioning all over again. I get it."

Wagner : "Listen, I've had boots on the ground in this country for a while now."

Elliot : "Ayolah Benny, jelaskan padaku, benar? Kau menyuruhku memanggil mereka kembali untuk ditanya ulang. Aku mengerti"

Wagner : "Dengarkan, aku sudah lama berada di negeri ini"

(Johnson, 2019, 00:23:08)

Pada perkataan Elliot terdapat sebuah kalimat ajakan come on dengan makna ayolah yang bermaksud untuk membujuk Benny agar dia mengatakan hal yang sebenarnya kepada Elliot.

\section{(4) Pembiaran}

Modalitas intensional yang memiliki makna pembiaran ini merupakan modalitas negasi dari modalitas ajakan. Modalitas ini membiarkan atau melepaskan mitra tutur untuk melakukan sesuatu.

Alice
Marta
Alice "It'm sorry Marta."
Marta : "Maaf, Marta"
(Johnson, 2019, 00:03:24)

Marta mengatakan It's okay kepada adiknya yang bernama Alice. Dia mengatakan itu setelah ibunya menyuruh Alice mematikan radio yang sedang didengarkan oleh Alice. Perkataan Marta dapat dikategorikan sebagai pembiaran karena membiarkan adiknya melanjutkan mendengarkan radio dan tidak mendengarkan perintah ibunya.

\section{(5) Permintaan}

Modalitas intensional bermakna permintaan merupakan modalitas yang berfungsi menggambarkan apa yang diinginkan oleh penutur terhadap mitra tutur atau sebaliknya.

Blanc : "May I just, um... Then I'll recede, but... As a self-made man myself, I have to express my admiration for how you followed in your father's footsteps."

Linda : "Thank you." 


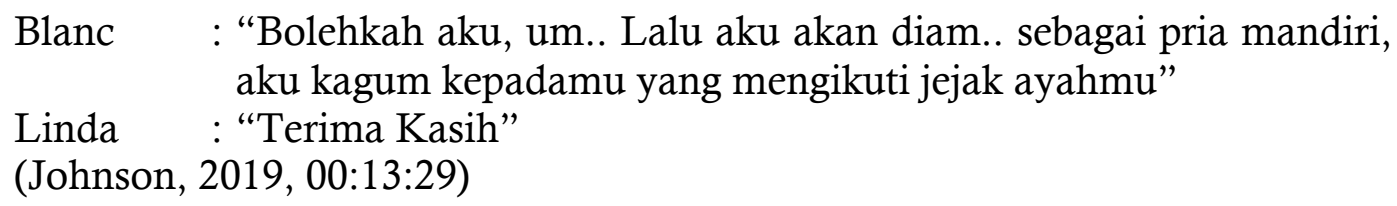

Blanc mengatakan May I just, um.. ketika dia meminta izin kepada Linda untuk menjelaskan mengapa dia bisa berada disitu. Frasa May I memiliki makna bolehkah aku yang mana berfungsi menyela percakapan dengan sopan.

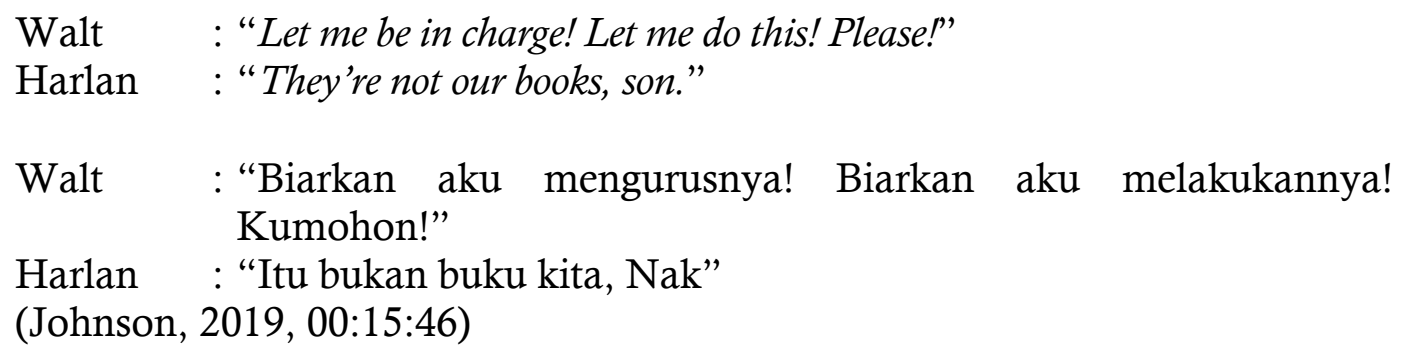

Dari perkataan Walt peneliti mendapatkan dua frasa yang menunjukkan permintaan, yaitu frasa let me dan please. Frasa let me memiliki arti biarkan aku, Walt mengatakan ini ketika meminta kepada Harlan agar tidak memecatnya. Adapun please berfungsi sebagai kata penekanan pada permintaannya.

\section{b. Epistemik}

Modalitas epistemik merupakan modalitas yang berfungsi untuk menyatakan asumsi atau sikap penutur berdasarkan keyakinan dan keraguannya terhadap proposisi (Coates, 1983, p. 18). Dalam film Knives Out, peneliti menemukan empat bentuk modalitas epistemik.

\section{(1) Kemungkinan}

Modalitas epistemik bermakna kemungkinan diungkapkan melalui kata, seperti: boleh, bisa, mungkin, dapat barangkali; dan frasa, seperti dapat saja, bisa saja, boleh saja, bisa jadi serta boleh jadi dengan memperhatikan aspek pada predikasi kalimatnya.

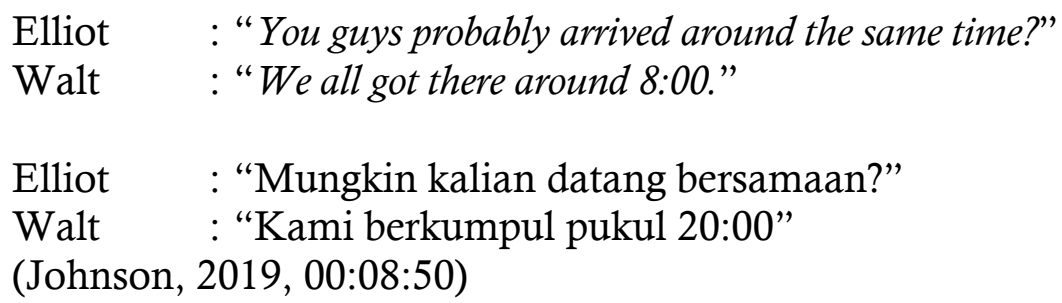

Dalam perkataan Elliot You guys probably arrived around the same time terdapat kata probably. Kata tersebut digunakan oleh Elliot untuk memastikan adanya sebuah kemungkinan jika mereka datang bersamaan atau di waktu yang berbeda.

\section{(2) Keteramalan}

Makna yang tergambarkan dari kata keteramalan menunjukkan sebuah tingkat keepistemikan yang nampak lebih tinggi darapada sebuah kemungkinan. 
Sebuah keteramalan memberikan sedikit gambaran dari sikap seorang penutur yang mana lebih meyakini terhadap adanya kebenaran daripada menunjukkan adanya kemungkinan. Sebuah kemungkinan hanyalah menggambarkan dari sikap penutur yang mana dia lebih tidak yakin terhadap sebuah kebenaran proposisi dari keteramalan. Adapula yang menyatakan bahwa sebuah keteramalan merupakan ungkapan akan, dugaan, perkiraan yang diwujudkan dalam kata, seperti sepertinya, rasanya, tampaknya, kelihatannya, dan juga sebuah frasa yang diikuti personal awal.

Joni : "I think Linda was upset. Hmm, but Harlan understood."

Elliot : "Right. Um, you two showed up to the party around the same time.."

Joni : "Kurasa Linda marah. Hmm, tetapi Harlan mengerti"

Elliot : "Baik. Um, Kalian berdua datang ke pesta bersamaan.."

(Johnson, 2019, 00:10:56)

Kalimat I think Linda was upset merupakan modalitas yang menyatakan sesuatu yang belum tentu benar adanya, hanya berdasarkan pada opini pribadi penutur. Pada kalimat tersebut ditandai dengan kata think sebagai penunjuk keteramalan.

Elliot : "All right, Blanc, I mean, this is..."

Blanc : "Yeah, yeah. Marta? We were just discussing possible motives in the family. I suspect that Harlan has told you."

Elliot : "Baik, Blanc, maksudku, ini..."

Blanc : "Ya, Marta? Kami baru membahas kemungkinan motif di keluarga. Aku menduga Harlan memberitahumu"

(Johnson, 2019, 00:24:29)

Dari perkataan Blanc I suspect that Harlan has told you dapat diketahui terdapat kata suspect untuk menyatakan pendugaan atau keteramalan yang belum pasti keabsahannya.

Wagner : "An envelope? That worked?"

Blanc : "An envelope of cash. Hmm. So somebody suspects foul play."

Wagner : "Amplop? Begitu saja?"

Blanc : "Seamplop uang. Hmm. Jadi seseorang menduga ada tindak kriminal"

(Johnson, 2019, 00:28:26)

Pada kalimat suspects foul play, Blanc menggunakan kata suspect lagi untuk menyatakan dugaannya. Blanc menjelaskan jika dia mendapatkan amplop dari seseorang yang menduga adanya tindak kriminal pada kematian Harlan. 


\title{
(3) Keharusan
}

Perbedaan antara sebuah keharusan dan perintah ada pada kadar restriksinya. Sebuah keharusan diungkapkan dengan beberapa kata seperti seharusnya, sebaiknya, seyogyanya, selayaknya dan juga sepatutnya.

\author{
Marta : "How are you?" \\ Linda : "You know, the funeral helped, I guess. Just seeing him. I thought you \\ should have been there." \\ Marta : "Apa kabar?" \\ Linda : "Pemakaman cukup meredakan duka. Kupikir seharusnya kau \\ ada di sana."
}

(Johnson, 2019, 00:04:57)

Dalam kalimat I thought you should have been there, Linda menyampaikan keharusan Marta hadir pada upacara pemakaman Harlan. Keharusan tersebut ditandai dengan kata should yang merupakan auxilary verb dan bermakna seharusnya.

\section{(4) Kepastian}

Modalitas epistemik yang memiliki makna kepastian menunjukkan adanya sikap penutur yang mana dia merasa bahwa dirinya pasti dan yakin akan sesuatu hal dengan benar. Sebuah kepastian ialah sikap dari penutur yang menyatakan dari kebenaran preposisi dengan tingkat keepistemikan tertinggi. Biasanya sebuah kepastian diungkapkan dengan ungkapan, seperti percaya, pasti, yakin, tentu, serta niscaya.

Elliot $\quad$ : Now, I happily obliged, and I can vouch for him."
Linda
Elliot $\quad$ : "Mr. Blanc, I know who you are."
Linda : "Tn. Blanc, aku mengenalmu."
(Johnson, 2019, 00:12:08)

Melalui perkataannya I can vouch for him, Elliot menyatakan sebuah kepastian kepada Linda yang pada saat itu menanyakan keberadaan Blanc di sana. Elliot menggunakan kata vouch yang memiliki arti menjamin untuk memberi kepastian kepada Linda.

\section{c. Deontik}

Deontik merupakan sebuah modalitas yang terfokus pada mitra tutur sebagai pelaku dari suatu peristiwa atau proposisi. Modalitas ini berfungsi sebagai pemberi izin (boleh atau larang) atau perintah (Alwi, 1992, p. 163). Dalam film Knives Out, peneliti menemukan dua bentuk modalitas deontik.

\section{(1) Perizinan}

Perizinan yang merupakan bagian dari deontik menunjukkan bahwa penutur sebagai seorang pelaku. Coates menyebut hal ini sebagai ciri kepelakuan (Coates, 1983, p. 93). Sumber deontik berasal dari peraturan di kalangan masyarakat 
tertentu sebagai kaidah atau norma sosial, seperti ungkapan izin menggunakan boleh, dapat, dan bisa. Agar dapat menjadi sumber diontik, maka ungkapan perizinan boleh, dapat, dan bisa harus didahului oleh penutur dari subjek persona kedua atau ketiga dan tidak boleh penutur subjek persona pertama. Jika memang ungkapan perizinan didahului oleh penutur subjek persona pertama, maka ungkapan perizinan tidak dapat disebut sebagai sumber diontik.

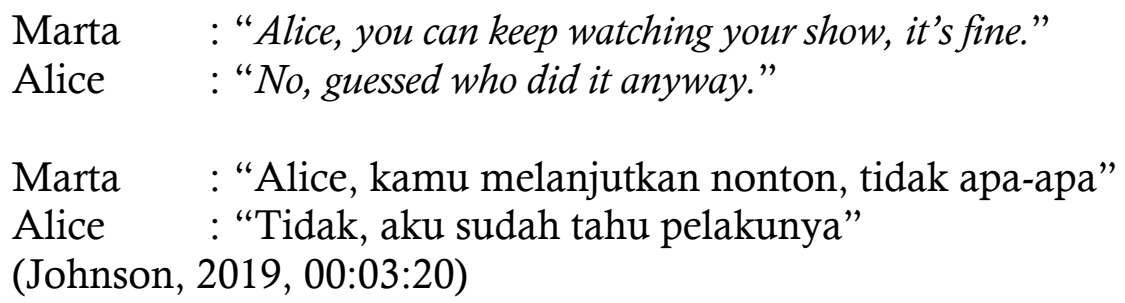

Dalam kalimat Alice, you can keep watching your show, it's fine, Marta mengizinkan kepada Alice untuk melanjutkan menonton. Perizinan itu terletak pada frasa can keep yang bermakna melanjutkan atau boleh tetap.

\section{(2) Perintah}

Perintah merupakan salah satu bentuk modalitas deontik yang memiliki makna perintah. Bentuk modalitas ini menempatkan penutur sebagai sumber deontik dan mitra tutur sebagai pelaku yang menjalankan sebuah kejadian atau peristiwa. Ungkapan penutur dalam memerintah kepada mitra tutur itu tidak hanya memberikan makna perintah melakukan pekerjaan tetapi terkadang juga memiliki makna agar tidak melakukan pekerjaan atau larangan.

$$
\begin{aligned}
& \text { Linda : "Why are you here?" } \\
& \text { Blanc : I'm here at the behest of a client." } \\
& \text { Linda : "Kenapa kau di sini?" } \\
& \text { Blanc : "Aku di sini atas utusan klien." } \\
& \text { (Johnson, 2019, 00:12:24) }
\end{aligned}
$$

Blanc menyatakan bahwasannya dirinya diperintahkan oleh seorang klien yang tidak diketahui melalui perkataan I'm here at the behest of a client. Dalam perkataan terdapat kata behest yang bermakna perintah.

Elliot : "Come on, Benny, talk to me, all right? Now, you tell me to invite all of the people back for questioning all over again. I get it."

Wagner : "Listen, I've had boots on the ground in this country for a while now."

Elliot : "Ayolah Benny, jelaskan padaku, benar? Kau menyuruhku memanggil mereka kembali untuk ditanya ulang. Aku mengerti."

Wagner : "Dengarkan, aku sudah lama berada di negeri ini."

(Johnson, 2019, 00:23:11) 
Elliot mengatakan Now, you tell me to invite all of these people back untuk menanyakan apakah dia diperintahkan untuk mengumpulkan keluarga Harlan. Frasa tell me pada dasarnya memiliki makna katakan padaku, akan tetapi pada konteks kalimat tersebut tell me bermakna menyuruhku.

\section{d. Dinamik}

Dinamik merupakan sebuah modalitas yang mana seorang pelaku menjadi objek dari aktualisasi peristiwa. Pelaku di sini dalam artian seorang yang dapat disebut sebagai nomina non-animate, namun terjadi selama nomina tersebut memberikan akibat atau timbal balik atas terjadinya suatu peristiwa. Modalitas ini berfungsi untuk menyatakan kemampuan pelaku (Palmer, 1979, p. 73). Peneliti menemukan satu bentuk modalitas dinamik dalam film Knives Out.

\section{(1) Kemampuan}

Kemampuan adalah salah satu jenis modalitas dinamik yang memiliki makna mampu, bisa, sanggup, atau dapat. Kata dapat, bisa, dan mampu digunakan hanya untuk merepresentasikan suatu bentuk kemampuan, sedangkan kata dapat dan bisa dipakai untuk mewujudkan kemampuan, perizinan, dan kemungkinan. Dapat dan bisa hanya dapat digunakan menyatakan izin jika subjek merupakan persona pertama dan ketiga. Kemampuan dianggap dapat dimiliki oleh subjek nomina tak bernyawa apabila nomina yang bersangkutan memiliki kemampuan yang dapat mengakibatkan terjadinya suatu peristiwa (Palmer, 1979, p. 73).

$$
\begin{aligned}
& \text { Harlan : "Get my robe and cap from my bedroom, and put them on." } \\
& \text { Marta : "Harlan, this is crazy. I don't think I can do that." } \\
& \text { Harlan : "Ambil jubah dan topi di kamarku, lalu kenakan." } \\
& \text { Marta : "Harlan, ini gila. Kupikir aku tidak bisa." } \\
& \text { (Johnson, 2019, 00:41:54) }
\end{aligned}
$$

Kalimat yang diungkapkan oleh Marta I don't think I can do that memiliki arti aku tidak berpikir aku bisa melakukannya jika diterjemahkan secara utuh. Dari penerjemahan tersebut dapat diketahui bahwa Marta tidak memiliki kemampuan untuk melaksanakan apa yang diperintahkan oleh Harlan.

\section{Proposisi}

Proposisi merupakan penyusun kasus yang dapat diketahui dengan adanya kata kerja yang ada dalam suatu kalimat (Arutjunova, 1975, pp. 5-14). Adapun penanda suatu kasus terdapat pada preposisi maupun postposisi, akan tetapi ada kalanya penanda tersebut dihilangkan. Dalam film "Knives Out," peneliti menemukan beberapa jenis proposisi yang peneliti rangkum dalam Tabel 2. 
Tabel 2. Jenis dan Bentuk Proposisi

\begin{tabular}{lll}
\hline Unsur Tata Bahasa Kasus & Jenis Proposisi & Bentuk Proposisi \\
\hline Proposisi & Agentif & Mereka \\
& & Anak Nazi \\
& Instrumen & Mesin tik \\
& Lokatif & Forklift \\
& Jalan \\
& Objektif & Pundak \\
& Artikel \\
& Eksperiens & Kata ganti orang ketiga \\
Sumber & Joni \\
& Tujuan & Proses kematian \\
& Bertemu \\
& Membayar \\
& Waktu & Investigasi \\
& Tahun \\
& Penyerta & Pukul \\
& Benefaktif & Anak \\
& & Orang-orang catering \\
\hline
\end{tabular}

Berdasarkan pada Tabel 2, proposisi dalam film "Knives Out" terdiri dari 10 jenis, yaitu: agentif (A), experiens (P), instrument (I), objek (O), sumber (S), tujuan (T), lokatif (L), waktu (W), penyerta (PNY), benefaktif (B). Masing-masing jenis proposisi ini mempunyai berbagai macam bentuk. Oleh karena itu, peneliti paparkan jenis proposisi dan bentuknya tersebut secara berurutan sebagaimana berikut ini.

\section{a. Agentif (A)}

Kasus agentif merupakan kasus dari penghasut atau pelaku bernyawa yang bertindak dan diidentifikasi oleh kata kerja (Connoly, 1987, pp. 129-161; Fillmore, 2003, p. 46).

Elliot : "But you remained close to the Thrombeys?"

Joni : "Oh! They're my family. I feel simultaneously freed by, and supported by them."

Elliot : : Kau tetap dekat dengan keluarga Thrombey?"

Joni : "Oh! Mereka keluargaku. Aku merasa bebas dan didukung oleh mereka."

(Johnson, 2019, 00:09:58)

Dalam potongan kalimat and supported by them, kita dapat mengetahui bahwasannya terdapat verba supported sebagai penanda kedudukan proposisi, kemudian them berlaku sebagai proposisi yang berkasus agentif karena berupa nomina dan terdapat preposisi berupa by sebagai penunjuk kasus $(\mathrm{K})$ agentif.

\section{b. Instrumen (I)}

Kasus instrumen merupakan kasus benda mati atau benda yang terlibat secara kausal dalam tindakan atau keadaan yang diidentifikasikan dengan kata kerja (Nilsen, 1970, pp. 271-277; Fillmore, 2003, p. 46). 
Richard : "Harlan started out with a rusty smith corona and built himself into one of the best-selling mystery writers of all time."

Elliot : "Wow, seems like all his kids are self-made overachievers."

Richard : "Harlan mulai dengan mesin tik berkarat dan menjadikannya salah satu penulis buku misteri terlaris."

Elliot : "Wow, sepertinya semua anaknya sukses secara mandiri."

(Johnson, 2019, 00:07:52)

Berdasarkan perkataan Richard started out merupakan verba penunjuk adanya kasus dalam suatu proposisi. Selanjutnya, kita mendapati penanda kasus $(K)$ berupa preposisi with yang merupakan salah satu preposisi penanda kasus instrumen. Setelah with kita menemukan a rusty smith corona, yang mana $a$ berfungsi sebagai determiner, rusty sebagai adverb dan smith corona merupakan kata instrumen. Dalam hal ini smith corona sebagai ungkapan lain dari typewrite atau keyboard.

Man 1 : "I didn't murder nobody!"

Man 2 : "You slashed his face open. You left him bleeding in the street like a stuck pig. Then you crushed his skull with a forklift."

Man 1 : "Aku tak membunuh!"

Man 2 : "Kau menggorok wajahnya. Kau tinggalkan dia berdarah di jalan seperti babi. Kemudian kamu menghancurkan tengkoraknya dengan forklift."

(Johnson, 2019, 00:02:40)

Perkataan orang kedua Then you crushed his skull with a forklift dalam radio tersebut terdapat verba berupa crushed sebagai penanda awal yaitu proposisi. Kemudian terdapar preposisi berupa with sebagai pengantar atau penanda adanya kasus instrumen. Setelah preposisi tersebut terdapat kata a forklift yang merupakan susunan determiner+noun sebagai kasus instrumen.

\section{c. Lokatif (L)}

Kasus lokatif merupakan kasus yang mengidentifikasi sebuah tempat kejadian, lokasi terjadinya sebuah peristiwa, atau gambaran spasial dari negara atau pekerjaan yang ditandai oleh kata kerja (Chu, 1999, pp. 29-34; Fillmore, 2003, p. 46).

Man 1 : "I didn't murder nobody!"

Man 2 : "You slashed his face open. You left him bleeding in the street like a stuck pig. Then you crushed his skull with a forklift."

Man 1 : "Aku tak membunuh!"

Man 2 : "Kau menggorok wajahnya. Kau tinggalkan dia berdarah di jalan seperti babi. Kemudian kamu menghancurkan tengkoraknya dengan forklift."

(Johnson, 2019, 00:02:44) 
Pada tuturan orang kedua you left him bleeding in the street like a stuck pig terdapat verba berupa left. Sedangkan kata in pada tuturan di atas sebagai preposisi pengantar kasus yang menuntun pada kasus lokatif yang ditandai dengan the street.

Elliot : "So the night went well."

Walt : "I mean, we're all gutted, but, uh, I was happy to have that night with him. To be by his side. To think about our books and what we've accomplished with them. It's like I can still feel his hand on my shoulder."

Elliot : "Malaitu berjalan lancar?"

Walt : "Kami semua sedih, tapi aku senang habiskan malam ini bersamanya. Berada di sisinya. Memikirkan buku kami. Ini seperti aku masih merasakan tangannya di pundakmu."

(Johnson, 2019, 00:09:29)

Dari perkataan Walt, kita memperoleh kata feel sebagai verba dalam pembentukan sebuah kasus. Kemudian on preposisi, my shoulder kasus lokatif dengan possessive pronoun berupa my.

\section{d. Objektif (O)}

Kasus objektif merupakan sebuah kasus yang paling netral secara semantik; apa pun yang dapat direpresentasikan oleh kata benda yang perannya dalam tindakan atau keadaan yang diidentifikasi oleh kata kerja dengan interpretasi semantik dari kata kerja itu sendiri (Fillmore, 2003, p. 46).

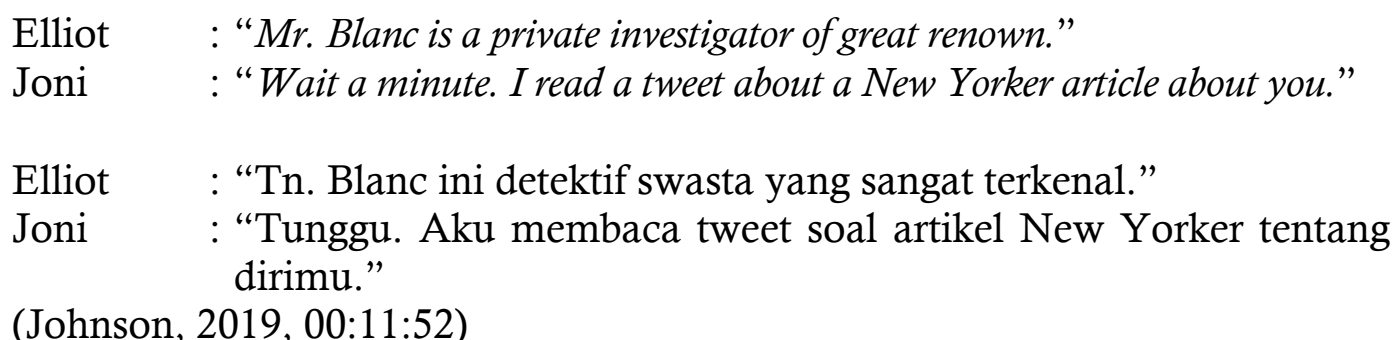

Kata read dalam ucapan Joni I read a tweet about a New Yorker article about you menjabat sebagai verba proposisi, kemudian terdapat kata a tweet sebagai kasus objektif yang disertai dengan awalan determiner. Sedangkan about a New Yorker article about you merupakan suplementer kalimat I read a tweet. Pada kasus objektif ini tidak diperlukan penanda khusus untuk menandakan bahwa kata tersebut merupakan sebuah kasus.

\section{e. Eksperiens (P)}

Kasus eksperiens adalah kasus yang menyatakan psikologi, sensasi, emosi, dan kognitif yang dialami oleh pelaku, akan tetapi tidak disertai dengan kata benda berupa instrumen (Yuwono, 2005, p. 212). 


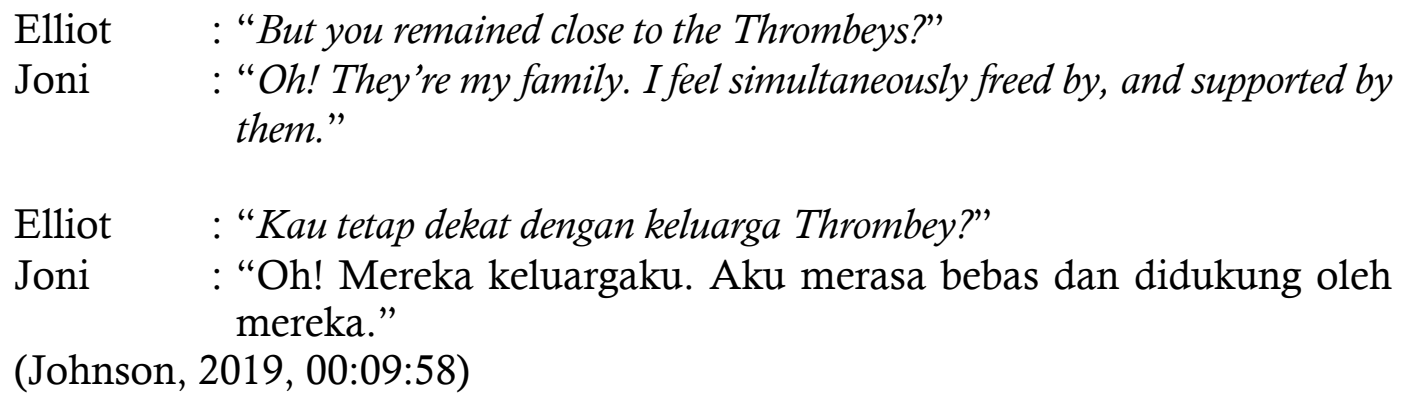

Berdasarkan perkataan tentang Thrombey, Jhoni menyatakan bahwa ia memiliki perasaan/emosi terhadap Thrombey ditandai oleh kata feel. Kata feel dalam perkataan itu sekaligus berkedudukan sebagai verba proposisi. Kasus eksperiens dalam I feel simultaneusly freed by adalah freed, sedangkan simultaneusly menjadi penegas bahwasan menurut Jhoni Thrombey dalam keadaan bebas atau tidak memiliki masalah.

\section{f. Sumber (S)}

Kasus sumber merupakan kasus yang menunjukkan verba sebagai penyebab terjadinya masalah atau keadaan (Tarigan, 2009, p. 63).

Elliot : "This is just some follow-up questions. Um, we're attempting to be thorough. So we can figure out the manner of death."

Walt : "So, by "manner of death, you mean if someone killed him?"

Elliot : "Ini pertanyaan lanjutan, kami ingin teliti. Supaya kita bisa tahu proses kematiannya."

Walt : "Proses kematian, maksudnya dia dibunuh?"

(Johnson, 2019, 00:11:22)

Pada tuturan Elliot di atas terdapat sebuah bentuk frasa verba yang ditunjukkan oleh kata figure out yang bertujuan untuk mengantarkan pada kalimat manner of death yang berkedudukan sebagai kasus sumber.

\section{g. Tujuan (T)}

Kasus tujuan $(G)$ merupakan kasus yang menyatakan tujuan dari suatu pekerjaan yang berupa noun (kata benda) (Tarigan, 2009, p. 62).

$$
\begin{aligned}
& \text { Elliot : "But you left the party early?" } \\
& \text { Meg : "To see some friends at Smith." } \\
& \text { Elliot : "Kau meninggalkan pesta lebih awal? } \\
& \text { Meg : "Untuk bertemu teman di Smith" } \\
& \text { (Johnson, 2019, 00:10:43) }
\end{aligned}
$$

Perkataan Meg To see some friends at Smith terdapat pengantar kasus berupa preposisi to untuk menunjukkan kasus tujuan dan kata see sebagai verba sekaligus kasus tujuan dalam kalimat tersebut. 
Elliot : "For the record, I'm speaking with Walt Thrombey. Harlan Thrombey's youngest son. So, you run your father's publishing company?"

Walt : "Yeah. It's my... It's our... Uh, it's the family's publishing company."

Elliot : "Untuk perekaman, aku sedang berbicara dengan Walt Thrombey. Putra bungsu Harlan Thrombey. Kau menjalankan perusahaan penerbit ayahmu?"

Walt : "Ya, itu milik kami. Itu perusahaan penerbit milik keluarga."

(Johnson, 2019, 00:08:04)

Seperti pemaparan kedua data di atas, pada perkataan Elliot ini kasus tujuan ditandai dengan adanya preposisi. Preposisi dalam perkataan tersebut adalah for, dan the record menjadi kasus tujuan dengan imbuhan determiner di depannya berupa the.

\section{h. Waktu (W)}

Kasus waktu adalah kasus yang menyatakan waktu kejadian yang dilakukan oleh verba pada waktu yang lampau, waktu sekarang atau saat ini dimana sebuah peristiwa sedang terjadi, maupun waktu yang akan datang (Tarigan, 2009, p. 90).

Elliot : "So, we're here with Joni Thrombey, Harlan Thrombey's daughter-inlaw?"

Joni : "Mmm-hmm. Yeah, I married his son, Neil. We had one daughter, Meg. And then Neil passed on 15 years ago."

Elliot : "Kami bersama Joni Thrombey, menantu Harlan Thrombey."

Joni : :Ya, aku menikahi putranya, Neil. Putri kami satu, Meg. Neil meninggal 15 tahun yang lalu."

(Johnson, 2019, 00:09:47)

Kita dapat mengetahui passed sebagai verba proposisi, verba yang berupa bentuk verb 2 yang menyatakan Neil telah meninggal. Selanjutnya on merupakan preposisi pengantar kasus dan 15 years ago sebagai kasus waktu karena menyatakan waktu kematian Neil.

\section{i. Penyerta (PNY)}

Kasus penyerta adalah kasus yang menyatakan orang atau benda yang menyertai suatu kejadian. Kasus penyerta ditandai dengan konjungsi berupa dengan, bersama dan with pada bahasa Inggris (Parera, 2009, p. 173).

Elliot : "For the record, I'm speaking with Walt Thrombey. Harlan Thrombey's youngest son. So, you run your father's publishing company?"

Walt : "Yeah. It's my... It's our... Uh, it's the family's publishing company."

Elliot : "Untuk perekaman, aku sedang berbicara dengan Walt Thrombey. Putra bungsu Harlan Thrombey. Kau menjalankan perusahaan penerbit ayahmu?"

Walt : "Ya, itu milik kami. Itu perusahaan penerbit milik keluarga." 
(Johnson, 2019, 00:08:04)

Tuturan Elliot im speaking with Whalt Thrombey merupakan kalimat yang di dalamnya terdapat kasus penyerta ditunjukkan dengan kata speaking sebagai verba yang berasal dari speak dan with merupakan preposisi yang berfungsi sebagai pengantar kasus yang ditujukan pada Walt Thrombey yang berkedudukan sebagai kasus penyerta.

\section{j. $\quad$ Benefaktif (B)}

Kasus benefaktif yaitu kasus yang ditujukan untuk menyatakan keuntungan ketika suatu pekerjaan dilakukan kepada objek berupa makhluk hidup (Tarigan, 2009, p. 62).

\section{Elliot : "Would you say that all three of you showed up around the same time?" Linda : "No. Richard comes early to help the caterers set up." \\ Elliot : "Apa kalian bertiga datang bersamaan?" \\ Linda : "Tidak. Richard datang terlebih dahulu untuk membantu orang- orang catering menyiapkan."}

(Johnson, 2019, 00:07:04)

Help pada perkataan tersebut sebagai verba proposisi, dan to merupakan preposisi yang berfungsi sebagai pengantar kasus. Dalam hal ini the caterers menjadi orang yang diuntungkan dalam aksi yang dilakukan oleh Richard. Oleh karena itu, the caterers adalah kasus benefaktif dalam perkataan Linda.

\section{PENUTUP}

Struktur kalimat pada film "Knives Out" berdasarkan perspektif tata bahasa kasus Charles J. Filmore terdiri dari: (1) empat jenis modalitas, yaitu: intensional, epistemik, deontik, dan dinamik; dan (2) sepuluh jenis proposisi, yaitu: kasus agentif (A), kasus eksperiens (P), kasus instrumen (I), kasus objektif (O), kasus sumber (S), kasus tujuan (T), kasus lokatif (L), kasus waktu (W), kasus penyerta (PNY), dan kasus benefaktif (B).

Temuan bahwa struktur kalimat di atas terdiri dari modalitas dan proposisi semakin menegaskan dan memperkuat penelitian-penelitian sebelumnya bahwa struktur kalimat dalam konteks tata bahasa kasus Charles J. Fillmore pasti terdiri dari modalitas dan proposisi. Modalitas dan proposisi ini memiliki berbagai macam jenis dan bentuk, memiliki fungsi yang berbeda-beda dalam sebuah struktur kalimat, dan juga mempunyai makna yang berbeda-beda pula tergantung pada ciricirinya yang melekat padanya dan letaknya.

\section{DAFTAR PUSTAKA}

Ackerman, F., Kay, P., \& O'Connor, M. C. (2014). Charles J. Fillmore. Language, 755-761.

Alfadhil, M. F., \& Rahmadi. (2020). Tata Bahasa Kasus Dalam Sosial Media Tweet Rocky Gerung Berdasarkan Perspektif Charles J. Filmore. In A. Basid, 
Linguistik Modern: Tata Bahasa Kasus dan Transmormatif Generatif (pp. 69-87). Malang: Edulitera.

Alwi, H. (1992). Modalitas Bahasa Indonesia. Yogyakarta: Kanisius.

Anderson, J. (1986). Structural Analogy and Case Grammar. Lingua, 79-129.

Arutjunova, N. (1975). Problem of Syntax and Semantic in the Work of Charles Fillmore. $\quad$ Linguistics, $13(150)$, 5-14. https://doi.org/10.1515/ling.1975.13.150.5

Basid, A., \& Inayati, I. R. (2020). Tata Bahasa Kasus Dalam Film Upin dan Ipin Berdasarkan Perspektif Charles J. Fillmore. In A. Basid, Linguistik Modern: Tata Bahasa Kasus dan Transformatif Generatif(pp. 3-48). Malang: Edulitera.

Basid, A., \& Maghfiroh, D. L. (2021, April). Case Grammar in the Movie "the Gentlemen" Based on the perspective of Charles J. Fillmore. (I. Zulaeha, Ed.) Seloka: Jurnal Pendidikan Bahasa dan Sastra Indonesia, 10(1), 77-87. https://doi.org/10.15294/SELOKA.V10I1.45491

Basid, A., Arzaqi, A. Z., \& Afiyanto, A. M. (2021). Case Grammar in Film "the Professor and the Madman" Based on Charles J. Fillmore's Perspective. Kembara: Jurnal Keilmuan Bahasa, Sastra, dan Pengajarannya, 7(1), 34-52. https://doi.org/10.22219/kembara.v7i1.15870

Bauer, M. W., \& Gaskell, G. (2007). Qualitative Researching with Text, Image, and Sound. London: Sage Publication.Inc.

Berg, B. L. (2001). Qualitative Research Methods for The Social Science. California: A Person Education Company.

Chaer, A. (2007). Linguistik Umum. Jakarta: PT. Rineka Cipta.

Chu, P. (1999). Verbs Are Not Cases: Applying Case Grammar to Document Retrieval. Information Processing Letters, 71(1), 29-34. https://doi.org/10.1016/s0020-0190(99)00080-0

Coates, J. (1983). The Semantics of Modal Auxiliaries. London: Croom Helm.

Connoly, L. (1987). Case Grammar and Word Order in German: The Case for Place by Case. Studies in Language, 11(1), 129-161. https://doi.org/10.1075/sl.11.1.06con

Cook, W., \& Platt, J. (1970). The Tagmemic-Case Grammar Model. American Speech, 45(3/4), 262-277. https://doi.org/10.2307/454843

D'Angelo, F. (1976). Notes toward a Semantic Theory of Rhetoric within a Case Grammar Framework. College Composition and Communication, 27(4), 359-362. https://doi.org/10.2307/356297

Ezzy, D. (2002). Qualitative Analysis: Practice and Innovation. Abingdon: Rouledge.

Fillmore, C. J. (2003). Form and Meaning in Language. Stanford: Centre for the Study of Language \& Information Publications.

Fletcher, P. (1971). Case Grammar. Lingua, 28, 237-350. https://doi.org/10.1016/0024-3841(71)90059-3

Gustianingsih. (2008). Modalitas dan Evidensialitas Bahasa Jawa. LOGAT Jurnal Ilmiah Bahasa dan Sastra, Vol. 4 No. 2, 42-54.

Indrawati, N., Bijaksana, M. A., \& Agustin, R. D. (2013). Pelabelan Peran Semantis Menggunakan Tata Bahasa Kasus. Jurnal Masyarakat Telematika dan Informasi, 04, 85-108.

Jurafsky, D. (2014). Obituary Charles J. Fillmore. Computational Linguistics, 725 731. 
Lakoff, G. (2014). Obituary of Charles J. Fillmore. Review of Cognitive Linguistics, 251-257.

Miller, R., Shibatani, M., \& Thompson, S. (1997). Essays in Semantics and Pragmatics in Honor of Charles J. Fillmore. Journal of the American Oriental Society, 117(3), 565-568. https://doi.org/10.2307/605255

Nilsen, D. (1970). Some Notes on Case Grammar in English. WORD, 26(2), 271277. https://doi.org/10.1080/00437956.1970.11435598

Nuessel, F. (1981). Case Grammar Development of the Matrix Model (19701978). Lingua, 83-88. https://doi.org/83-88. https://doi.org/10.1016/00243841(81)90030-9

Pak, T. (1974). Absurdities in Fillmore's Case Grammar. Studia Linguistica, 19-50.

Palmer, F. R. (1979). Modality and the English Modal. London: Longman.

Parera, J. D. (2009). Dasar-Dasar Analisis Sintaksis. Jakarta: PT. Penerbit Erlangga.

Suparnis. (2008). Tata Bahasa Kasus (Case Grammar). Jumal Bahasa dan Seni, 8(2), $126-131$.

Tarigan, H. G. (2009). Pengajaran Tata Bahasa Tagmemik. Bandung: CV. Penerbit Angkasa.

Tarigan, H. G. (2009). Pengkajian Pragmatik. Bandung: CV. Penerbit Angkasa.

Trijp, R. V. (2017). The Evolution of Case Grammar: Computational Models of Language Evolution 4. Berlin: Language Science Press.

Verhaar, J. (2010). Pengantar Linguistik. Yogyakarta: Gajahmada University Press.

Yuwono, U. (2005). Pesona Bahasa: Langkah Awal Memahami Linguistik. Jakarta: PT. Gramedia Pustaka Utama.

Zaim, M. (2014). Metode Penelitian Bahasa: Pendekatan Struktural. (Ermanto, Ed.) Padang, Indonesia: FBS UNP Press. 